\title{
The impact of political decisions on the tourist accommodation occupancy - Central Europe in the time of the COVID-19 pandemic
}

\author{
Bartosz KORINTH
}

\begin{abstract}
Tourism is one of the most dynamically developing branches of many national economies, remaining to this day one of the most important industries in the world. However, the outbreak of the COVID-19 pandemic, or to be more precise, radical measures introduced by most governments to prevent its spread, have led to its collapse. The aim of the article is to look at the changes in the occupancy of tourist accommodation facilities (which resulted from political decisions) and to indicate which of these decisions seem most justifiable and relevant. When it comes to the research area, Central Europe was chosen as it is a region which, in the last few years, has recorded annual increases in international tourist traffic. Based on the results of the study conducted, we may state that all Central European countries have recorded a decrease in the occupancy of tourist accommodation facilities in the period from March to June 2020 (a decrease of app. 85\% in comparison to the same period last year). Among the least affected by the crisis are Austria, Switzerland, and Slovenia. The situation in the so-called Alpine countries is due to the fact that their governments decided to unfreeze the economy quite early.
\end{abstract}

Keywords: accommodation, politic, Central Europe, COVID-19, pandemic

\section{Introduction}

Tourism is one of the most dynamically developing economic sectors, generating more than $9 \%$ of the world's GDP. The current economic crisis connected with the COVID-19 pandemic, which became evident in the first half of 2020, largely affected tourism as well as other sectors. According to UNWTO data, in the period between January and August, the number of international tourist arrivals noted a fall of $70 \%$, which means that the losses were equal to approximately 730 billion USD (UNWTO 2020). When it comes to the impact of the world's economic recession, the tourism sector has suffered greatly, especially if we consider the amount of tourism investments, the profitability of tourism enterprises as well as tourist traffic intensity. Comparably, the world's economic crisis of 2008 had a similar effect on tourism (Kurek and Waclawik 2013).

The aim of the article is to present the impact of governmental decisions on the occupancy of tourist accommodation in July 2020, when the crisis of the tourism sector was evident. The actions undertaken by governments, that is, specific COVID-19 regulations and borders' closure have been scrutinised as they are seen by the author as the main factors affecting the occupancy of tourist accommodation. For the purposes of this analysis, data from the European Statistical Office has been used (Eurostat 2020).

\section{Research area}

While scrutinising the impact of the COVID-19 pandemic, one should begin with what is meant by the term Central Europe. As per the generally accepted definition, it is defined as the area between Eastern and Western Europe, even though its specific boundaries are understood differently, depending on the historical period (Ash 1999). The terminological ambiguity related to the research area is mentioned, among others, by Wendt (1998) and Okey (1992).

DOI: https://doi.org/10.33542/GC2021-1-02 
Both agree that due to a variety of definitions, precise specification in the context of each research work is required. Some subject literature treats Central Europe as an equivalent of the Visegrad Group (Kořan 2012) i.e. a region spanning the Czechia, Hungary, Poland, and Slovakia. Because of socio-economic similarities, Slovenia is also seen as a part of the group. On the other hand, in 1994, the International Geographical Union in Prague determined that, while scientific publications in the field of geography refer to Central Europe, it is understood as a region consisting of nine countries - those belonging to the Visegrad Group (Czechia, Poland, Hungary, Slovakia) and those located in the Alps - Austria, Germany, Switzerland, Slovenia and Lichtenstein (Kučera 1994). This broad definition of Central Europe has been applied in this paper. An impact of political actions related to the COVID-19 pandemic on the occupancy of tourist accommodation facilities, is studied for all countries mentioned i.e. for Central Europe.

\section{Research background}

The tourism industry is one of the most important and dynamically developing economic sectors - it generates app. $10 \%$ of the world's gross product. Its importance is also perceivable on the European continent itself, which, according to the UNWTO, is the area with the highest number of international tourist arrivals, oscillating around 700-750 million annually (Ostertag and Wöber 2010). In the subject literature, it is estimated that about $20 \%$ of these arrivals concerns the area analysed by the author. Interesting research on the intensity of tourist traffic in the central part of Europe was carried out by Batista et al. (2018), who concluded that this intensity, reflected, among others, by the tourist density indicator, mainly covers urbanised areas. However, the value itself varies over time and is subject to the specific qualities of the so-called Alpine countries, where a strong concentration of tourist traffic occurs mainly in winter (Pechlaner and Tschurtschenthaler 2003). The analysis of tourist traffic in the Visegrad Group countries was carried out by Kozoň and Cuper (2016), who pointed at a constantly rising trend when it comes to foreign tourists' participation in the occupancy of accommodation facilities. The increase in the importance of tourism in the region studied was caused by the dynamic development of infrastructure, which was, in turn, possible thanks to the policy of the European Union (e.g. as part of the Cohesion Fund).

Looking upon statistical data and analysing the studies regarding international tourist traffic in Central European countries, one could have expected a continuous rise both in the number of passengers from abroad and in the occupancy of accommodation facilities by foreign tourists. However, the situation has changed dramatically since March 2020, when WHO proclaimed COVID-19 a new pandemic (Cascella et al. 2020). Back then, many countries closed their borders and introduced numerous restrictions directly related to e.g. maintaining social distance and wearing a mask (Baker et al. 2020, Homolak et al. 2020). Moreover, the introduction of quarantine by more and more countries has been vital in the context of tourism. Equally, essential has been the popularization of the SARS-CoV-2 coronavirus test, recognised as a part of the tactical fight against its further spread (Cohen and Kupferschmidt 2020). The functioning of the entire accommodation base, restaurants, pubs, and other elements of the infrastructure accompanying foreign tourists was largely limited (Dube et al. 2020). While analysing the undertakings of Central European governments, the dates when the borders were closed for international tourists seem meaningful (Eckardt et al. 2020).

The first country to close its borders entirely (with the exception of international freight transport) was Czechia. In the same period, a sanitary cordon was introduced at the borders of Poland, significantly limiting border traffic (Regulation by the Minister of Interior and Administration on 13 March 2020). On 16 March, other countries from the researched area i.e. Germany, Hungary, and Switzerland - closed their borders. A day later (17 March 2020), the rest of the EU countries also decided to close the borders and this decision was incorporated in the European Commission's communication on temporary travel restrictions in the European Union. Later in March, more countries officially announced lockdowns (tab. 1). The exception 
was Switzerland, whose government on 20 March 2020, announced that the country's economic activity will not be halted, but only the way it functions will change (Willi et al. 2020).

The term "lockdown" refers to the situation in which a country decides to considerably limit civil liberties as well as economic freedom in order to combat the impact of the COVID19 pandemic, which poses a direct threat to citizens' health. This phenomenon is closely connected with, among other actions, the closure of borders and the introduction of numerous restrictions concerning the functioning of accommodation and gastronomic base.

Tab. 1. Dates of the introduction of lockdown in the countries of Central Europe

\begin{tabular}{lc}
\hline Country & Date of the introduction of lockdown \\
\hline Poland & $13 / 03 / 2020$ \\
Czechia & $16 / 03 / 2020$ \\
Austria & $16 / 03 / 2020$ \\
Slovenia & $20 / 03 / 2020$ \\
Slovakia & $20 / 03 / 2020$ \\
Germany & $23 / 03 / 2020$ \\
Hungary & $28 / 03 / 2020$ \\
\hline
\end{tabular}

Source: Own elaboration

After the economic slowdown in March and the closure of borders, the countries of Central Europe attempted to escape from the global crisis as quickly as possible (Loayza et al. 2020). The first European country to ease the restrictions surrounding the COVID-19 situation was Austria (tab. 2), which already opened thousands of small stores on April 14, 2020. Soon afterwards, Germany and Switzerland announced plans to reopen their economies. A great step for tourism in the above-mentioned countries was the statement of the Austrian Chancellor, Sebastian Kurz, who announced that due to the great importance of tourism for the Austrian economy, the government decides to open its borders for German tourists, usually planning their trips to Italy (Schmidt et al. 2020). On 4 June, Austria, Germany, Switzerland, Lichtenstein, Slovenia, Hungary, Slovakia, and Czechia, in order to at least partially save the tourism industry, signed an international agreement concerning the opening of borders between them (Desson, 2020). Currently, as a result of another wave of the pandemic, the countries of Central Europe have introduced new regulations regarding foreign travel.

In some of the countries, the possibility to travel between them has been maintained, while in others, any tourist movement has been halted. Additionally, some countries (including Slovenia) have introduced a mandatory COVID-19 test that must be valid at least 48 hours before the planned trip. The lack of another travel ban traffic may have been motivated by the unfavourable situation of hotel owners who, as a consequence of a significant decrease in the accommodation base in the period from March to June 2020, have had problems with maintaining financial liquidity (Jones and Comfort 2020).

As of now (November 9, 2020), the analysed region is struggling with a growing number of confirmed SARS-CoV-2 cases. New records in the number of COVID-19 cases have been reached in, among others, Poland, and the Czechia (currently seen as the European country most affected by the pandemic). Statistical data collected from various sources demonstrate a uniform trend for all Central European countries, where the number of cases is now returning to the level recorded in March or exceeding it.

It needs to be underlined that the tourism sector is constantly undergoing changes caused by factors connected to the international situation as well as by various local and country implications. One of the main dangers when it comes to tourism development is the issue of the world's security state. A number of publications mention such threats as, for instance, international terrorism in the United States (Pizam and Feischer 2002) or the unstable situation 
in the Arabic countries related to the so-called Arab Spring. The series of events now associated with the Arab Spring led to a significant fall in passenger air traffic in Tunisia and Egypt in 2011 (Wendt 2019).

Tab. 2. Regulations concerning tourism in Central European countries during the COVID-19 pandemic (as of: 9 November 2020)

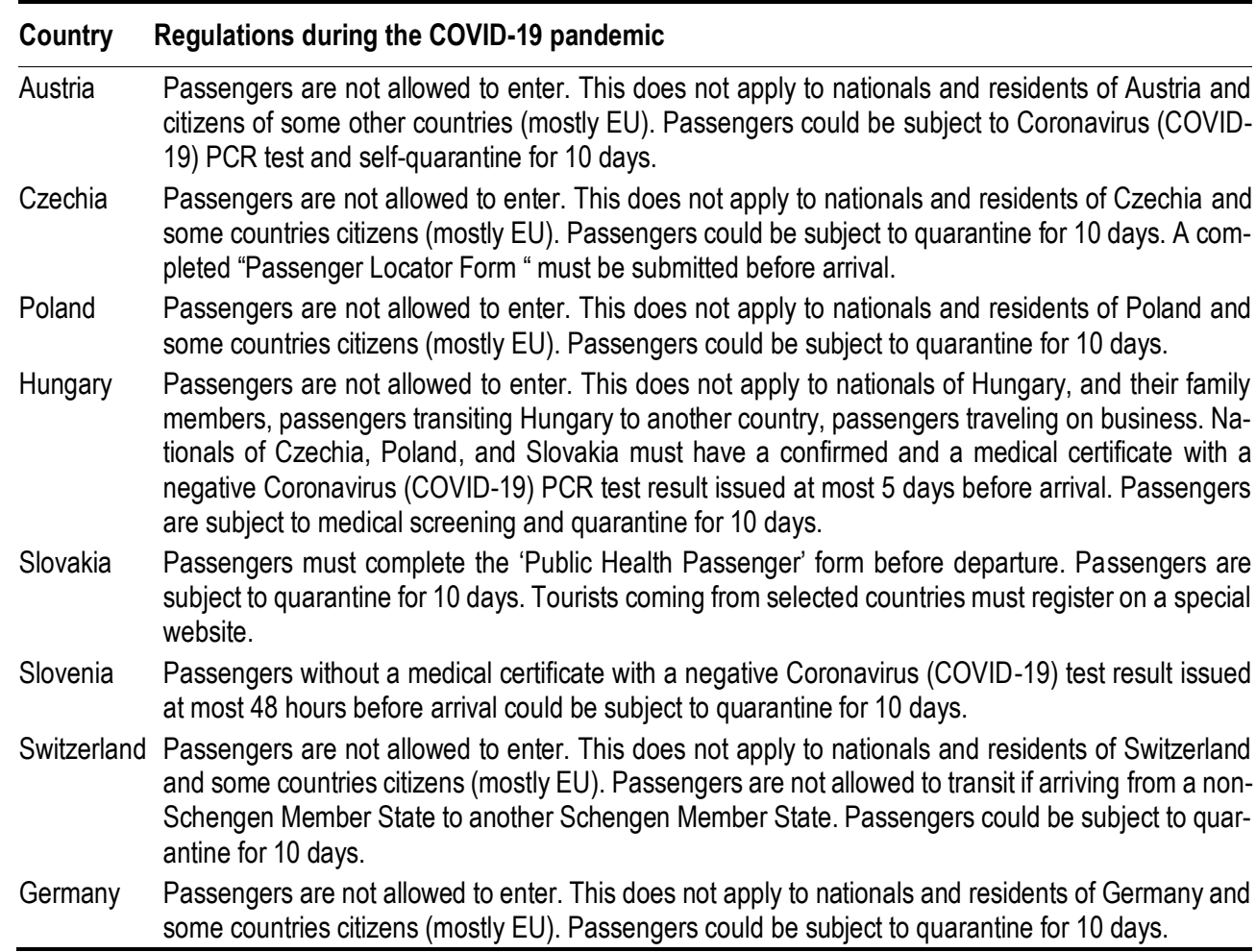

Source: IATA (2020)

The factors influencing how the structure and dynamics of the tourist market are shaped also include changes in the model and lifestyle of tourists and their perception of a given tourist destination. It is assumed that the image is indeed the basic element that builds competitiveness on the tourist market and thus increases the number of tourists in a respective destination (Baloglu and McCleary 1999). Tourism is also affected by other global factors, such as climate change or natural disasters i.e. hurricanes, earthquakes, and floods (Rosselló et al. 2020). Therefore, it can be stated that the COVID-19 pandemic is not the only contemporary threat to the condition of tourism but merely its manifestation.

\section{Materials and methods}

In order to examine the impact of political decisions surrounding the COVID-19 pandemic on the occupancy of tourist accommodation facilities in Central Europe, it was decided to use data from Eurostat - the European Statistical Office (Eurostat 2020).

The study employs the methods commonly used in statistics - forecasting based on the ARIMA model and hierarchical analysis using the Agglomerative NESting (AGNES) algorithm (fig. 1). The tool to use the above-mentioned methods was R programming. Such programming choice was mainly determined by its enormous capabilities in the field of data analysis (including time series important for this work) and its ever-growing popularity. Due to its popularity, a huge number of scientific publications with a variety of practical tips and 
recommendations is available (e.g. Pebesma et al. 2012,). The analysed countries were divided due to changes in the occupancy of the accommodation base in July 2020 and July 2019. High occupancy refers to values above the sum of the mean and the standard deviation. Low occupancy refers values below the sum of the mean and the standard deviation. Medium occupancy refers values between the mean and the standard deviation.

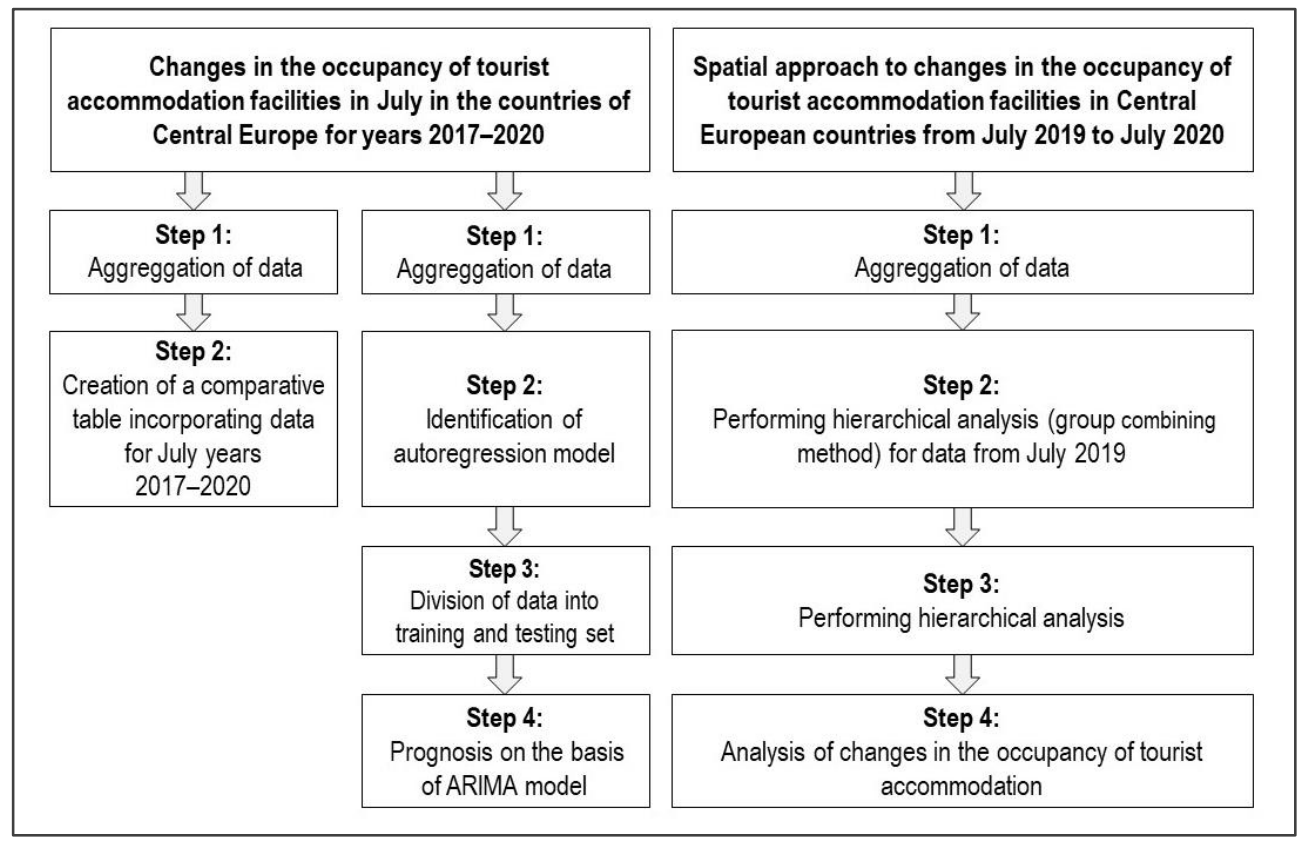

Fig. 1. Steps of research methods; Source: Own elaboration

\section{Results and discussion}

There are many publications concerning the importance of tourism in Central European countries. However, none of them predicted the enormous economic crisis caused by the spread of the COVID-19. In each of the Central European countries, the loss of up to $85 \%$ has been recorded in comparison to the previous year.

The Visegrad Group countries, in comparison to the "Alpine countries", faced a much lower occupancy of tourist accommodation facilities in July (fig. 2), although, a slight rising trend is discernible. The highest number (per 1,000 residents) of tourists that yearly used accommodation facilities in Austria, Slovenia, and Switzerland is probably due to their geographical location and the great importance of these countries for mountain tourism. This is confirmed by the research of Dolnicar and Leisch (2003), who conclude that the winter tourist industry is key for entire country economies. Data from July 2020 depict great shifts in the occupancy of tourist accommodation facilities throughout Central Europe. Compared to the corresponding period for the previous years, all countries have recorded losses of app. 85\%, which is the result of political actions related to the COVID-19 pandemic and the consequent global crisis.

A slight long-term rising tendency has been noticed for the countries analysed (fig. 3). The forecast for the period from January to June 2020 shows that most of them should be facing a rapid growth trend at that time, resulting, among others, from the onset of the "holiday season". Subject literature affirms that in countries such as Poland, Czechia, or Slovakia, the peak of tourist traffic falls between May and September (Vágner 2007). On the other hand, a slight fall in the first half of 2020 was predicted for Austria and Switzerland, which both record the peak season in winter i.e. from November to March. During these months, the occupancy of tourist accommodation facilities is the highest in these countries (Carraher and Parnell 2008). 
However, no prognosis predicted a relatively large decrease in the analysed variable that was caused by the negative impact of the COVID-19 pandemic. Those changes have been largely affected, among others, by the closure of borders and the introduction of restrictive measures related to foreign travel, which in turn contributed to the sudden and unpredictable changes visible also in the charts.

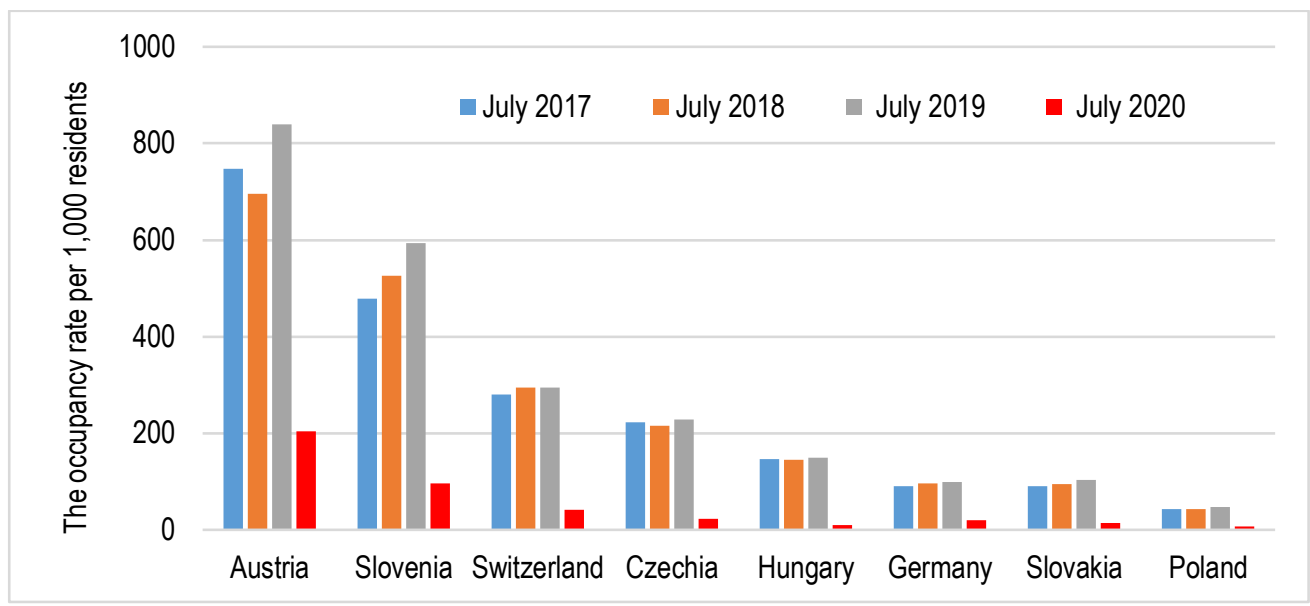

Fig. 2. The occupancy rate of tourist accommodation facilities in July in the countries of Central Europe in years 2017-2020, per 1,000 residents; Source: Own elaboration

based on data from the Statistical Office of the European Union (Eurostat 2020).
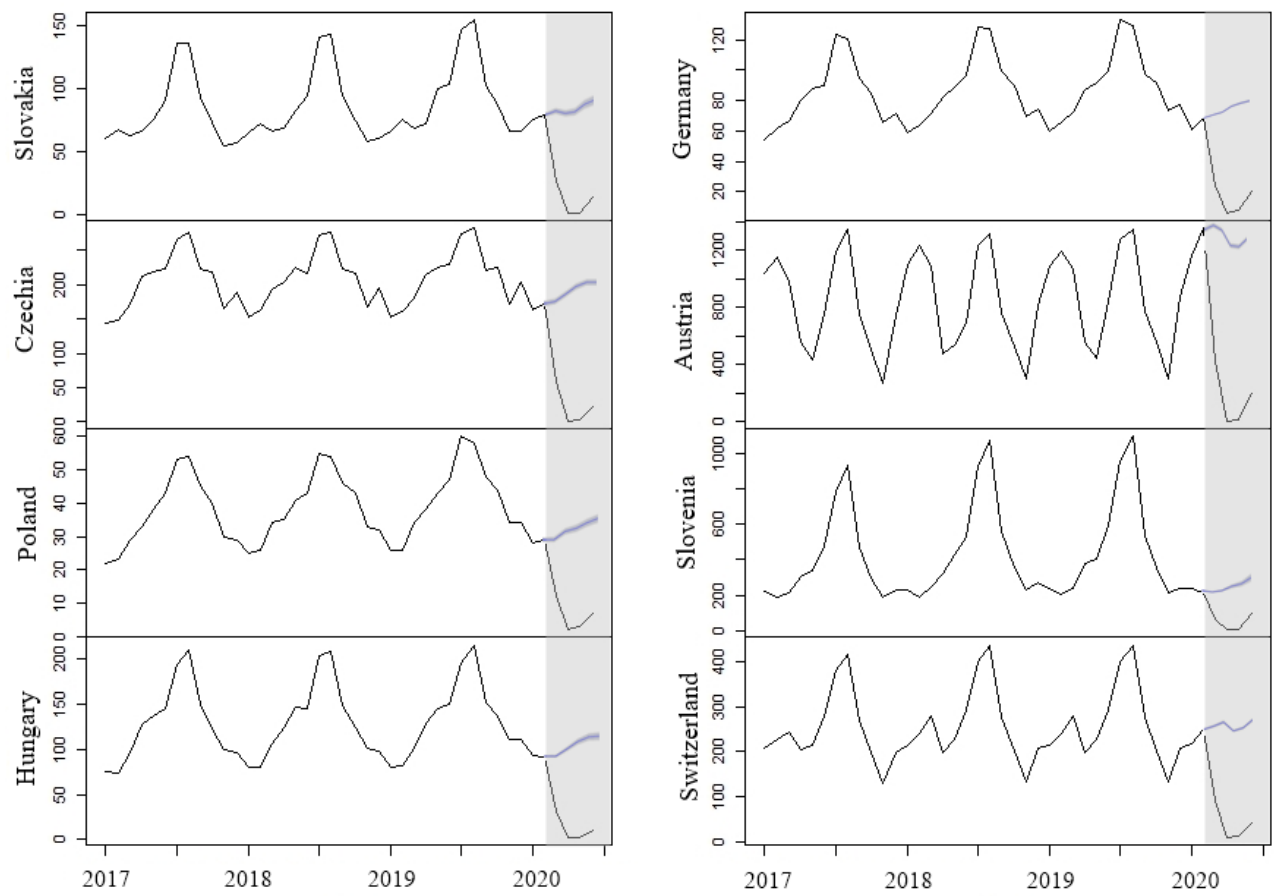

Fig. 3. Changes in the occupancy of tourist accommodation facilities in July in the countries of Central Europe for years 2017-2020, per 1,000 residents - prognosis and the actual state; Source: Own study based on data from the Statistical Office of the European Union

(Eurostat 2020). 
The spatial analysis of changes in the occupancy of the accommodation base (fig. 4) allows to distinguish countries that were characterized by high values of the variable. Such results do not differ from the trends presented in the previous part of the article. Taking into account the collected statistical data, it is possible to distinguish Central Europe's "tourist winners" in the COVID-19 pandemic. These so-called winners are mainly Austria, Switzerland, and Slovenia - countries with high or medium occupancy of tourist accommodation facilities in comparison to the rest of the countries concerned, for both periods. They probably succeeded thanks to the international agreement signed on 4 June, and of the quick reopening of borders to foreign tourists (also in Austria and Switzerland). A clearly lower differentiation of the analysed variable was observed in the Visegrad Group countries, which, both before and after the outbreak of the pandemic, suffered from lower occupancy of tourist accommodation facilities per 1,000 people.

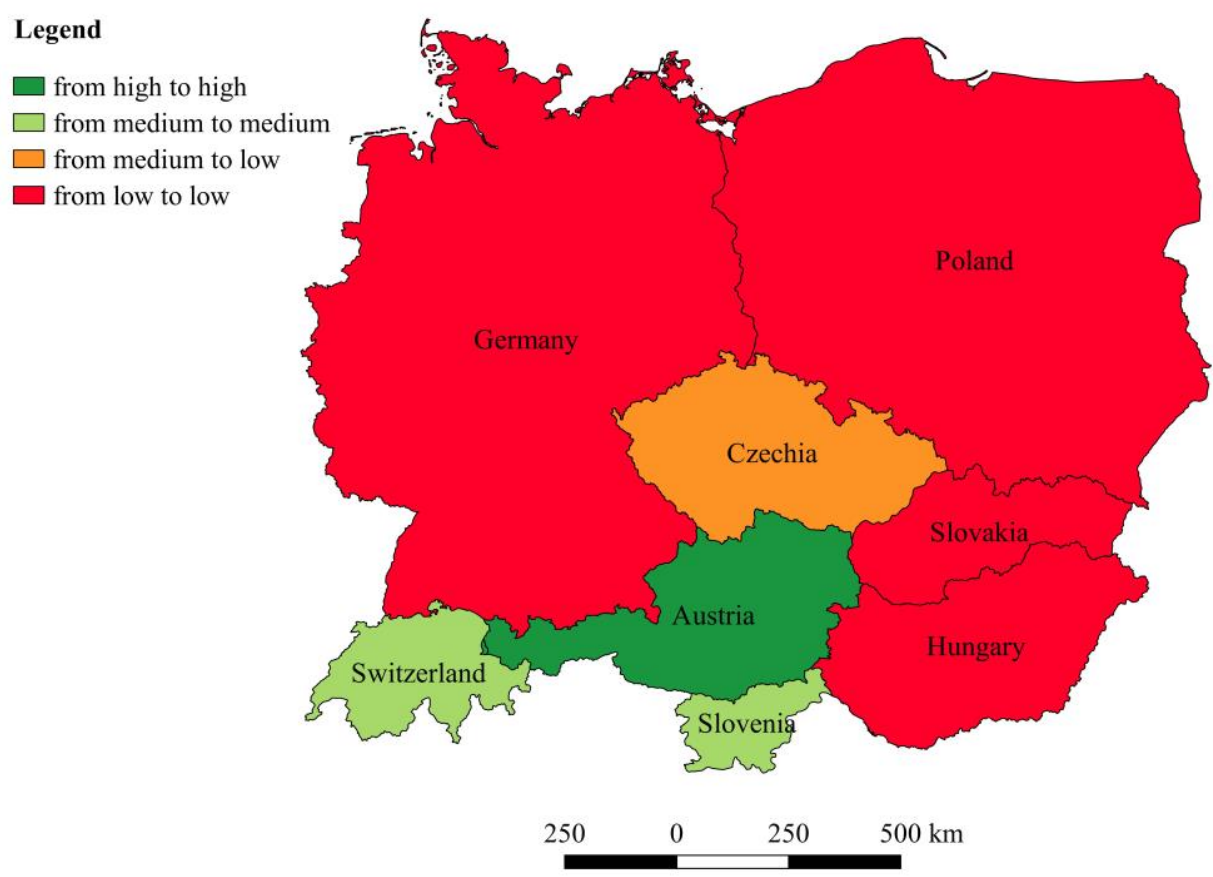

Fig. 4. Spatial approach to changes in the occupancy of tourist accommodation facilities in Central European countries from July 2019 to July 2020, per 1,000 inhabitants; Source: Own study based on data from the Statistical Office of the European Union (Eurostat 2020).

Although the impact of the COVID-19 pandemic on tourism is widely discussed in the world literature, the topic elaborated upon in this article is not that popular. When it comes to other studies dealing with the this topic, particularly the publication of Kreiner and Ram (2020) deserves special attention as the authors highlight the fact that the state of tourism depends on political decisions, i.e. the implementation of various solutions shaping the nature and the extent of tourist accommodation facilities occupancy. The authors, similarly, to this paper, conclude that the reason for the decline in the analysed variable is the start date of national preventive measures (e.g. closing borders). Similar implications of political actions on the development of tourism in the pandemic era can also be found in the publication of Seyfi et al. (2020), which clearly indicates that the time of introducing travel restrictions (lockdown) is closely related to tourist traffic. 
A lot of space in subject literature is devoted to the issue of the variable analysed in this paper, that is, the occupancy of tourist accommodation facilities. The article presented by Hossain (2020) states that the occupancy rate in China fell by $95 \%$ in the first week of March in comparison to the first week of January 2020. Evidently, the decline is even worse than in the countries of Central Europe, which recorded a decrease at the peak of the tourist season by $85 \%$ (see fig. 3). This significant discrepancy in the declining percentage is probably due to the introduction of more restrictive measures by the Chinese government, including the complete isolation of residents. The occupancy of accommodation facilities in selected Polish cities analysed by Korinth and Ranasinghe (2020) is also characterized by a similar decrease of $70 \%$ when compared to the corresponding period in the previous year, although this data concerns the very beginning of the pandemic in Europe (March 2020). Therefore, it can be said that the above-mentioned statistics correspond to the results of the study presented in this article. What is more, they all confirm the general downward trend in the occupancy rate of tourist accommodation facilities in Central Europe.

\section{Conclusions}

The analysis of all data introduced above points to the fact that the occupancy rate of tourist accommodation facilities in Central European countries was relatively low and was characterized by a significant fall of app. $85 \%$ when compared to the same period last year. This was the result of radical political decisions made in order to contain the spread of the COVID-19 pandemic. These decisions, to a greater or lesser extent, affected the entire area analysed by the author, though, they did not change the position of those countries which yearly experienced the highest occupancy of tourist accommodation facilities per 1,000 residents i.e. Austria and Switzerland. It is difficult to predict how the values of the analysed variable will evolve in the future, as the pandemic continues, or, to say more, a significant increase in confirmed cases has been recorded in recent weeks.

We may assume that both the occupancy of tourist accommodation facilities and its further developments (related also to the generated GDP) will mainly depend on individual decisions of governments. At the same time, it seems that no radical decisions will be taken, as the economies are still unstable. Most likely, we will not be facing a complete closure of state borders to travellers, which would lead to an unwanted harming of the entire tourism industry that has just been trying to get back on its feet.

\section{References}

ASH, G. T. 1999: The puzzle of central Europe. The New York Review, 46(5). Retrieved from: https://www.nybooks.com/articles/1999/03/18/the-puzzle-of-central-europe/.

BAKER, S. R., BLOOM, N., DAVIS, S. J., KOST, K., SAMMON, M., VIRATYOSIN, T. 2020: The unprecedented stock market reaction to COVID-19. The Review of Asset Pricing Studies, 10(4), 742-758. DOI: https://doi.org/10.1093/rapstu/raaa008.

BALOGLU S., MCCLEARY K. W. 1999: A Model of Destination Image Formation. Annals of Tourism Research, 26(4), 868-897.

CARRAHER, S., PARNELL, J. A. 2008: Customer service during peak (in season) and nonpeak (off season) times: A multi-country (Austria, Switzerland, UK \& USA) examination of entrepreneurial tourist focused core personnel. International Journal of Entrepreneurship, 12, 39-56.

CASCELlA, M., RAJNIK, M., CUOMO, A., DUlEBOHN, S. C., DI NAPOLI, R. 2020: Features, Evaluation and Treatment of Coronavirus. Treasure Island (StatPearls Publishing). Retrieved from: https://www.ncbi.nlm.nih.gov/books/NBK554776/.

COHEN, J., KUPFERSCHMIDT, K. 2020: Countries test tactics in 'war'against COVID-19. Science, 367(6484), 1287-1288. DOI: https://doi.org/10.1126/science.367.6484.1287. 
DESSON, Z., LAMBERTZ, L., PETERS, J. W., FALKENBACH, M., KAUER, L. 2020: Europe's Covid-19 Outliers: German, Austrian and Swiss policy responses during the early stages of the 2020 pandemic. Health Policy and Technology, 9(4), 405-418. DOI: https://doi.org/10.1016/j.hlpt.2020.09.003.

DOLNICAR, S., LEISCH, F. 2003: Winter Tourist Segments in Austria: Identifying Stable Vacation Styles Using Bagged Clustering Techniques. Journal of Travel Research, 41(3), 281-292. DOI: https://doi.org/10.1177/0047287502239037.

DUBE, K., NHAMO, G., CHIKODZI, D. 2020: COVID-19 cripples global restaurant and hospitality industry. Current Issues in Tourism, in press, 1-4. DOI: https://doi.org/10.1080/ 13683500.2020 .1773416$.

ECKARDT, M., KAPPNER, K., WOLF, N. 2020: Covid-19 across European Regions: The Role of Border Controls. Working Paper DP15178. London (Centre for Economic and Policy Research).

EUROSTAT 2020: Tourism statistics - occupancy rates in hotels and similar establishments. Luxembourg (Statistical office of the European Union).

HOMOLAK, J., KODVANJ, I., VIRAG, D. 2020: Preliminary analysis of COVID-19 academic information patterns: a call for open science in the times of closed borders. Scientometrics, 124(3), 2687-2701. DOI: https://doi.org/10.1007/s11192-020-03587-2.

HOSSAIN, M. 2020: The effect of the Covid-19 on sharing economy activities. Journal of Cleaner Production, 280(1), 124782. DOI: https://doi.org/10.1016/j.jclepro.2020.124782.

IATA 2020: COVID-19 Travel Regulations Map. Official International Air Transport Association (IATA) Website. Retrieved from: https://www.iatatravelcentre.com/world.php.

JONES, P., COMFORT, D. 2020: The COVID-19 crisis and sustainability in the hospitality industry. International Journal of Contemporary Hospitality Management, 32(10), 30373050. DOI: https://doi.org/10.1108/IJCHM-04-2020-0357.

MINISTER OF INTERIOR AND ADMINISTRATION 2020: Journal of laws of the Republic of Poland, Warsaw, 13 March 2020 item 435.

KORINTH, B., RANASINGHE, R. 2020: Covid-19 pandemic's impact on tourism in Poland in March 2020. GeoJournal of Tourism and Geosites, 31(3), 987-990. DOI: https://doi.org/ $10.30892 /$ gtg.31308-531.

KOŘAN, M. 2012: The Visegrad Group on the Threshold of Its Third Decade: A Central European Hub? In Šabič, Z. et al. eds. Regional and international relations of Central Europe. London (Palgrave Macmillan), pp. 201-218. DOI: https://doi.org/10.1057/9781137283450_11.

KOZOŇ, J., CUPER, J. 2016: Štatistika cestovného ruchu v krajinách Vyšehradskej štvorky. Forum statisticum Slovacum, 12(2), 67-76.

KREINER, N. C., RAM, Y. 2020: National tourism strategies during the Covid-19 pandemic. Annals of tourism research, in press, 103076. DOI: https://doi.org/10.1016/j.annals.2020.103076.

KUČERA, T. 1994: Important Prospect: International Geographical Union Regional Conference on Environment and Quality of Life in Central Europe: Problems of Transition, to be held in the Palace of Culture, Prague, Czech Republic, during 22-26 August 1994. Environmental Conservation, 21(1), p. 86. DOI: https://doi.org/10.1017/S0376892900024309.

LOAYZA, N. V., SANGHI, A., SHAHARUDDIN, N., WUESTER, L. 2020: Recovery from the pandemic crisis: Balancing Short-Term and Long-Term Concerns. Research \& Policy Briefs From the World Bank Malaysia Hub, 38, 1-13. Retrieved from: https://openknowledge.worldbank.org/handle/10986/34462. 
OKEY, R. 1992: Central Europe / Eastern Europe: Behind the Definitions. Past \& Present, 137, 102-133.

OSTERTAG, J., WÖBER, K. W. 2010: European city tourism statistics. In Mazanec J.A., Wöber K. W. eds. Analysing International City Tourism. Vienna (Springer), pp. 25-41. DOI: https://doi.org/10.1007/978-3-211-09416-7_3.

PEBESMA, E., NÜST, D., BIVAND, R. 2012: The R Software Environment in Reproducible Geoscientific Research. Eos, Transactions American Geophysical Union, 93(16), p. 163. DOI: https://doi.org/10.1029/2012EO160003.

PECHLANER, H., TSCHURTSCHENTHALER, P. 2003: Tourism Policy, Tourism Organisations and Change Management in Alpine Regions and Destinations: a European Perspective. Current Issues in Tourism, 6(6), 508-539. DOI: https://doi.org/10.1080/ 13683500308667967.

PIZAM, A., FLEISCHER, A. 2002: Severity versus Frequency of Acts of Terrorism: Which Has a Larger Impact on Tourism Demand?. Journal of Travel research, 40(3), 337-339. DOI: https://doi.org/10.1177/0047287502040003011.

SCHMIDT, A. E., LEICHSENRING, K., STAFLINGER, H., LITWIN, C., BAUER, A. 2020: The impact of COVID-19 on users and providers of long-term care services in Austria. International Long-Term Care Policy Network. Retrieved from: https://tccovid.org/2020/04/16/theimpact-of-covid-19-on-users-and-providers-of-long-term-care-services-in-austria/.

SEYFI, S., HALL, C. M., SHABANI, B. 2020: COVID-19 and international travel restrictions: the geopolitics of health and tourism. Tourism Geographies, in print, 1-17. DOI: https://doi.org/10.1080/14616688.2020.1833972.

UNWTO 2020: Impact assessment of the covid-19 outbreak on international tourism. Official World Tourism Organization Website [cit. 2020-12-31]. Retrieved from: https://www.unwto.org/impact-assessment-of-the-covid-19-outbreak-on-international-tourism.

WENDT, J. 1998: Współpraca regionalna Polski w Europie Środkowej. Studia europejskie, 4(8), 133-146.

WENDT, J.A. 2019: Comparison of the impact of the Arab Spring and terrorist attacks on the decline in tourism in Egypt and Tunisia (2010-2015). GeoJournal of Tourism and Geosites, 27(4), 1367-1376. DOI: https://doi.org/10.30892/gtg.27421-440.

WILLI, Y., NISCHIK, G., BRAUNSCHWEIGER, D., PÜTZ, M. 2020: Responding to the COVID-19 Crisis: Transformative Governance in Switzerland. Tijdschrift voor economische en sociale geografie, 111(3), 302-317. DOI: https://dx.doi.org/10.1111\%2Ftesg.12439.

VÁGNER, J. 2007: Tourism development in the Visegrad Four countries in the period of the EU access. AUC Geographica, 42(1-2), 75-89.

\section{Author's affiliation}

\section{Bartosz Korinth}

University of Gdańsk

Faculty of Oceanography and Geography, Institute of Geography

Fieldorfa 1, 80-041 Gdańsk

Poland

bartosz.korinth@wp.pl 